\title{
Efficiency of immune biosensor based on total internal reflection ellipsometry at the determination of Salmonella
}

\author{
Nickolaj F. Starodub ${ }^{1}$, Julia O. Ogorodnijchuk ${ }^{2}$ \\ ${ }^{1}$ National University of Life and Environmental Sciences of Ukraine, Gerojev Oborony Str. 15, Kiev, \\ Ukraine,nikstarodub@yahoo.com
}

\begin{abstract}
It was investigated the efficiency of the immune biosensor based on the total internal reflection ellipsometry (TIRE) comparing with surface plasmon resonance (SPR) based biosensors for determination of such bacteria as Salmonella in model solutions. It has been defined that in case with Spreeta sensitivity was on the level $10^{3}-10^{7} \mathrm{cells} / \mathrm{ml}$. Another biosensor based on the SPR has shown the sensitivity within $10^{1}-10^{6}$ cells $/ \mathrm{ml}$. The maximal level of sensitivity was obtained using TIRE based device and it was on the level of several cells in $10 \mathrm{ml}$ (up to the fact that less than 5 cells). The optimal time of the sample incubation with the transducer surface was about 15 min Also it was evaluated possibility of practical application of the above mention instrumental approaches.
\end{abstract}

Key words: immune biosensor, total internal reflection ellipsometry, determination, salmonella

\section{Introduction}

Salmonella typhimurium, along with other representatives of salmonella, is the causative agent of food toxic infection. It enters into the human body with food, causes severe food poisoning. The source of the infections is often foods contaminated with living microorganisms, mostly meat, eggs, etc. Infection may be because of slaughtering sick animals, failure to comply with sanitary standards in the processing of products directly from bacilli carriers and in violation of the rules of storing and transporting food. The traditional methods of the diagnostics of this infection disease often include three phases: microbiological, serological and biological analysis [1]. Unfortunately, this complex of approaches is routine and performance of each of them is rather routine, expensive and requires the use of the stationary equipments and high professional level. To help overcome these shortcomings, at least at the stage of screening or of purely serological testing we it is proposed using modern methods of biosensors. So, in previous in vestigations we used a two different types of optical immune biosensors based on the "Plasmonotest" developed in the Institute of Cybernetics of Ukrainian National Academy of Sciences and Spreeta model (USA) modified in this Institute [2. 3]. It has been defined that first type device has sensitivity within $10^{1}-10^{6}$ cells $/ \mathrm{ml}$ and second one on the level $10^{3}-10^{7}$ cells $/ \mathrm{ml}$. The obtained range of sensitivity is agree with that obtained by others authors [2-4, 6-8] with this type of optical immune biosensors. Unfortunately, as a rule, the infection dose of bacteria is much less and it demands to search ways for increasing level of the determination or obtaining more highest total sensitivity of analysis as results of complex approaches including a special procedure of sample preparation. This article is devoted appreciation of the efficiency of TIRE as transducer of immune biosensor at the bacteria determination in comparison with the different types of SPR.

\section{Experimental}

Spreeta is a device with three channels. It may directly connect to the computer for the registration of optical signal and its processing in advance. Moreover, this biosensor may have built in a simple computer unit and may be improved by GPS system, which can provide the immediately transferring of the obtained results in the stationary laboratory for the further verification of analysis and making appropriate decisions to restrict of the infection source. Sensitive module surface (which was presented gold layer) was connected with special flow through cell and liquor injection control system as well as thermistor for temperature stabilization and control. 
Principle of "Plasmonotest" working is very close to Spreeta module organization. It is optical device of angular type based on the SPR principle, which is equipped with CCD array of 2048 pixels. Angular resolution of devise is 0.001 degree. Additionally the flowing cell for liquor pumping and temperature stabilization could be mounted on the sample. Accuracy of temperature stabilization in flow cell is at least $0.1^{\circ} \mathrm{C}$. One more difference is that detecting layer is formed on the glass plate surface covered by 1-2 $\mathrm{nm}$ niobium adhesive film and $50 \mathrm{~nm}$ gold plasmonsupporting film connected with prism using immersion liquid. This is more favorable because glass plates can be easily changed or/and renewed. Furthermore it allows providing of all surface preparations in advance.

As a basis for TIRE biosensor, a commercial spectroscopic rotating analyzer instrument $\mathrm{M}$ 2000 V, J.A. Woollam Co. was used operating in the 350-1000 $\mathrm{nm}$ wavelength range. Detecting layer was formed on the chromium/gold-coated glass plate attached to a 68 trapezoidal glass prism (BK7, $\mathrm{n}=1.515)$. This prism provides total internal reflection effect between glass and aqueous solutions $(n=1.33)$. The samples analysis was provided using a specially designed $1.5 \mathrm{~cm}^{3}$ cell attached through a rubber ring. The injection of different solutions into the cell was carried with inlet and outlet tubes. Using the prism polarized white light was coupled to the sample. After passing through another polarizing element (analyzer) the reflex beam was collected with photodetector array.

To achieve high density of the immobilization of the immune components on the transducer surfaces they were preliminary treated by polyalylamine hydrochloride (PPA). After that the transducer surface was prepared with the help of protein A from Staphylococcus aureus for the oriented immobilization of specific antibodies. The "direct" algorithm was as main way of analysis when the specific antibodies that were immobilized on the transducer surface interact with solution contented different concentration of antigen.

In case with Spreeta and Plasmonotest after Ab immobilization transducer surface was covered with bovine serum albumin (BSA) for blocking free non-specific binding centers on the gold surface. BSA powder was provided by Sigma (USA). It had been observed that surface treatment using BSA after $A b$ immobilization did not make any contribution in the refraction angel quantity. It means that there were no blanks on the gold surface and $A b$ concentration was enough for dense layer forming.
For detection using Spreeta it was prepared the model diluted solution of $S$. typhimurium with the number of concentrations (from $10^{3}$ to $10^{8}$

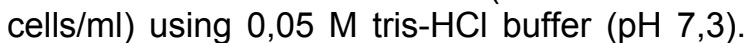
The time of the sample incubation with the transducer surface was about $5 \mathrm{~min}$ and after that the last was washed by the above mentioned buffer.

For analysis using "Plasmonotest" model solution was prepared using $0.9 \%$ saline solution and dilution range of $S$. typhimurium was from $10^{1}$ to $10^{6}$ cells $/ \mathrm{ml}$. The time of the sample incubation with the transducer surface was about $10 \mathrm{~min}$ and after that, the last was washed by the saline solution.

In case of TIRE biosensor transducer surface was prepared the same way as for SPR sensors. The anti-salmonella serum (St. Petersburg Research Institute of Vaccines and Serums, Russia) at $1: 2$ dilutions in $0,85 \%$ of $\mathrm{NaCl}$ solution was placed on the working chip and it was incubated for $30 \mathrm{~min}$ in humid conditions and then washed with the PB. The prepared chips were stored in dry state at $4^{\circ} \mathrm{C}$. Range of dilution of initial $S$. typhimurium solutions was made in such way that $10 \mathrm{ml}$ contained 1 and more cells (up to $10^{5}$ ). The time of the sample incubation with the transducer surface was about $15 \mathrm{~min}$. It was observed that received value almost did not change after $30 \mathrm{~min}$ incubation. Maximal level of sensitivity was on the level of several cells in $10 \mathrm{ml}$ (up to the fact that less than 5 cells).

\section{Results and discussion}

In the case of Spreeta based biosensor it has been defined that device sensitivity was on the level $10^{3}-10^{7}$ cells $/ \mathrm{ml}$. Son J R and others had also used Spreeta for detection of Salmonella enteritidis. In their article they reported that antiSalmonella antibodies had been immobilized on the gold sensor surface using neutravidin. The sensor sensitivity they had got was on the level $10^{5} \mathrm{cfu} / \mathrm{ml}$ [4]. Comparing with previous results we can conclude that sensor sensitivity depends of transducer surface preparation method and can be noticeably improved using application of biological layers as is described above. The diagram of the obtained results is presented in Fig. 1 (the changes of microorganism concentrations are indicated by the pointers from above and the start of washing - by ones from bellow).

"Plasmonotest" sensitivity was within $10^{1}-10^{6}$ cells $/ \mathrm{ml}$. It's higher than in Spreeta case but it is not sufficient for all practice situations. Obtained results are shown in Fig. 2. 


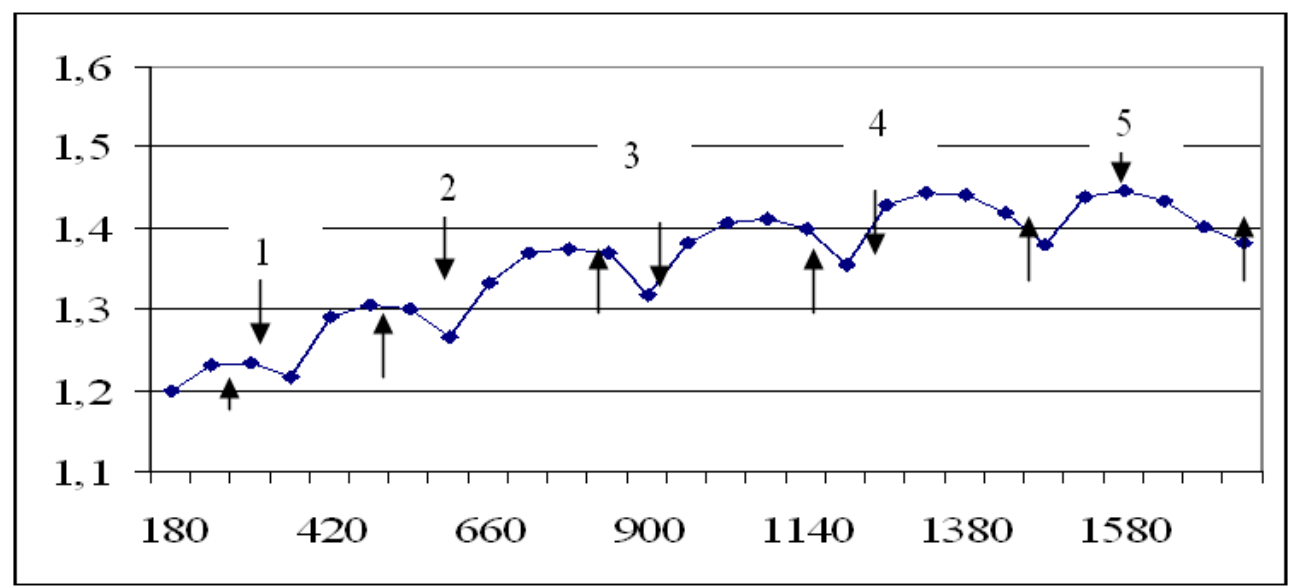

Fig. 1. Sensor diagram of S. typhimurium solutions analysis. 1-5-10 $0^{3}-10^{7}$ cells $/ \mathrm{mL}$. Abscissa - time (sec) and ordinate - change of resonant angle.

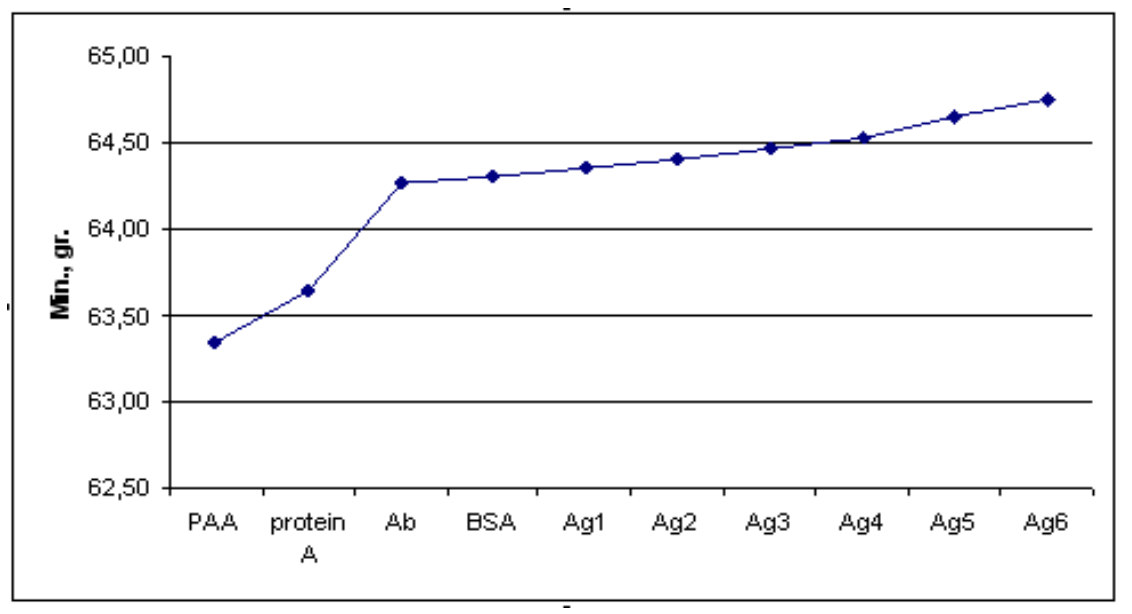

Fig. 2. Diagram of S. typhimurium solutions analysis using "Plasmonotest".

Biosensor based on the TIRE has shown higher sensitivity than the SPR based. Maximal level of sensitivity was on the level of several cells in $10 \mathrm{ml}$ (up to the fact that less than 5 cells). The experimental results are presented in Fig. 3.

Also it is necessary to pay attention to the effective methods of previous food samples preparation especially to the methods of bacteria cells concentration in the solution which will be examined next.

The obtained results and their comparison with the existing literature data obtained by the immune biosensor of similar type are presented in Table 1.

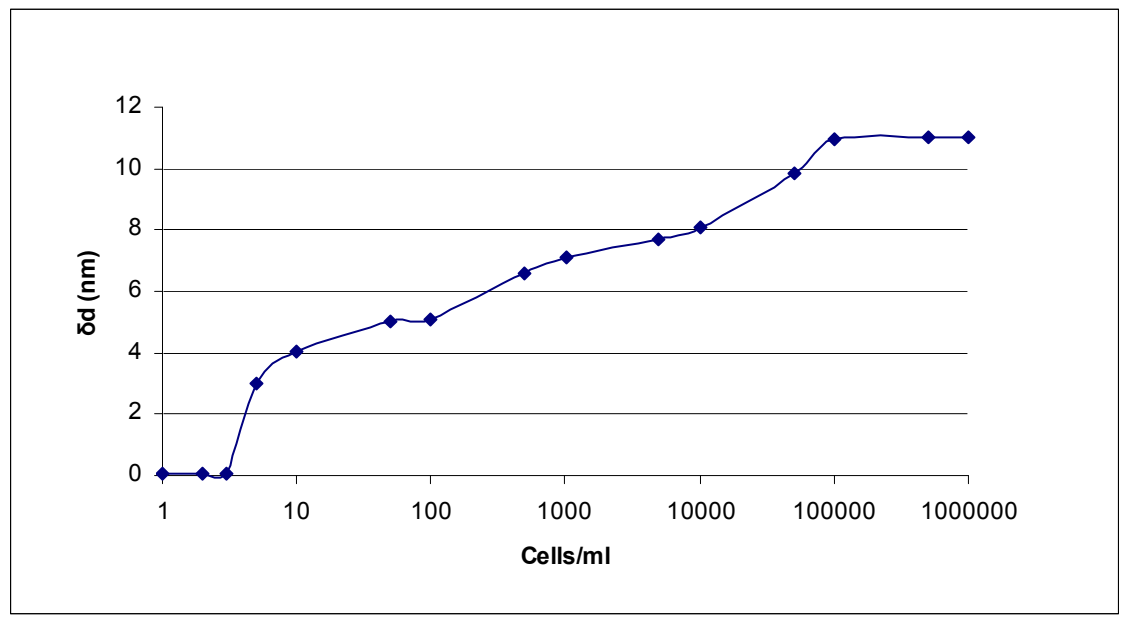

Fig. 3. Diagram of S. typhimurium solutions analysis using TIRE based immune biosensor. 
Tab. 1: Comparison the results of $S$. typhimurium determination in the solution obtained by optical immune biosensors [2-3, 6-8].

\begin{tabular}{|c|c|}
\hline Type of immune biosensor & Limit determination \\
\hline "Spreta" module, intermediate layers - PPA, protein A & $10^{3}-10^{4}$ cells ml ${ }^{-1}$ \\
\hline "Spreta" module, intermediate layers - PPA, protein G & $2 \times 10^{2}-10^{3}$ cells $\mathrm{ml}^{-1}$ \\
\hline $\begin{array}{l}\text { "Spreta" module, intermediate layers - dodecanthiol, protein A) } \\
{[3-4]}\end{array}$ & $5 \times 10^{3}-10^{4}$ cells $\mathrm{ml}^{-1}$ \\
\hline "Plasmonotest", intermediate layers - PAA, protein A & $10^{1}$ cells $\mathrm{ml}^{-1}$ \\
\hline TIRE, intermediate layers - PPA, protein A) & 5 cells $10 \mathrm{ml}^{-1}$ \\
\hline "Biacore", intermediate layer - developed dextran & $1.7 \times 10^{3} \mathrm{FU} \mathrm{ml}^{-1}$ \\
\hline SPR, direct physical adsorption & $10^{6}$ cells $\mathrm{ml}^{-1}$ \\
\hline SPR, intermediate layer - mercapto-undecanoic acid, protein G & $10^{2}$ cells $\mathrm{ml}^{-1}$ \\
\hline
\end{tabular}

One can see the biosensor based on the TIRE has higher sensitivity than the SPR based ones. Maximal level of sensitivity was on the level of several cells in $10 \mathrm{ml}$ (up to the fact that less than 5 cells). It is the highest level of the sensitivity among of well-known immune biosensors.

As a rule, the sensitivity of the immune biosensor analysis does not sharply depend on way of the preliminary treatment of the transducer surface excluding situation when intermediate layer was absolutely absent. In our case, with the TIRE based immune biosensor the signal was decreased in such way that the level sensitivity was up to two orders less than if the intermediate layer from PAA and protein A was created. In case of formation of such layer from protein $A$ only the above mentioned sensitivity was less about on one order than if both components (PAA and protein $A$ ) were used. We consider that this situation is connected with the blocking of the antigenbinding centers from one site and with the increasing of density of $A b$ immobilization on the transducer surface from other ones. As it is well known the protein $A$ has up to fife centers for $\mathrm{Ab}$ binding and blocking some of them did not prevent that remained to interact with $\mathrm{Fc}$ fragments of $A b$. PAA, maybe, provides a high density of protein $A$ immobilization on the electrostatic transducer surface.

The infection dose of pathogenic microorganisms is less than 10 cells per $100 \mathrm{ml}$ [5] therefore to fulfill practice demands and to bring sensitivity of analysis to a necessary level a new ways to enrich a test samples should be developed.
The needed sensitivity for practice may be achieved by several ways one of them is the application of specific Ab with high level of affinity and it may be done by using some monoclonal $\mathrm{Ab}$. Other way is in the development of special algorithm of sample preparation prior its analysis by the immune biosensor.

\section{References}

[1] Laboratory diagnostics of salmonellosis, detection of salmonellas in foods and environment. Methodical Guidance, MG 2.272510, M, 49 (2010)

[2] N.F. Starodub, Ju.O. Ogorodnijchuk, V.O. Romanov, I.B. Galeljuka, I.M. Kushnir, Sci. Bull. 151 (2), 183-189 (2010)

[3] N.F. Starodub, Ju.A. Ogorodnijchuk, V. O. Romanov, In Book: "The Sensor+Test 2011 Conference", 139-144 (2011)

[4] J. R. Son, G. Kim, A. Kothapalli, M.T. Morgan, D. Ess, Detection of Salmonella enteritidis using a miniature optical surface Plasmon resonance biosensor, Journal Physics 61, 1086-1090 (2007)

[5] D. Ivnitski, I. Abdel-Hamid, P. Atanasov, E. Wilkins, Biosensors and Bioelectronics 14, 599624 (1999)

[6] C.A. Gertie, M. Bokken, R.J. Corbee, F.van Knapen, A. A. Bergwerff, Journal FEMS Microbiology Letters 222, 75 - 82 (2003)

[7] V. Koubova, E. Brynda, L. Karasova, J. Sïkvorc, J. Homola, J. Dostalek, P. Tobisïka, J. Roslicky Sensors and Actuators B74, 100-105 (2001)

[8] B.K. Oh, Y.K. Kim, K.W. Park, W.H. Lee, J.W. Choi, Biosensors and Bioelectronics 19, 14971504 (2004) 